\title{
Novos rumos para a Revista Brasileira de Geociências
}

Para quem faz parte da comunidade geológica brasileira, a Revista Brasileira de Geociências (RBG) tem sido a publicação mais evidente, habitual e representativa para veicular as suas contribuições científicas. Como periódico trimestral, tem contado, desde o seu início, há mais de 40 anos, com um fluxo continuado e invejável de manuscritos submetidos para publicação.

Ao receber o honroso convite da Sociedade Brasileira de Geologia para ocupar o cargo de Editor Chefe da RBG, resolvi aceitá-lo como um instigante desafio, colocando meus melhores esforços no sentido de buscar incrementar a visibilidade e a importância internacional da revista. Tenho grande afeto por ela, pois eu a vi nascer, resultado do esforço e dedicação de Fernando de Almeida junto ao Conselho Nacional de Desenvolvimento Científico e Tecnológico (CNPq). Na ocasião, a SBG confirmou o Professor Fernando para Editor Chefe, e fui indicado para ajudá-lo, como Editor Associado. Cinco anos depois, minha responsabilidade aumentou, ao assumir a chefia da RBG no quinquênio 1975-80 e, até hoje, portanto durante mais de três décadas, permaneci no seu quadro de revisores.

Em 40 anos de RBG, todos nós, os editores anteriores, conseguimos manter o padrão sério da publicação e, ademais, no último período, o Editor Chefe Pio Fiori e seus colaboradores conseguiram expressivo progresso na implantação do sistema eletrônico Open Journal Systems (OJS) para os trabalhos editoriais, e uma grande vitória na obtenção da pontualidade. A RBG está hoje disponível tanto em meio digital quanto impresso, e desde o começo de 2012 está indexada na base de dados internacional SCOPUS.

Em 2011, a diretoria da SBG promoveu uma importante reestruturação editorial da revista. Concordo plenamente com os novos rumos fixados, indicados em sua mensagem divulgada no número de junho, que incluem manter a regularidade da publicação e buscar indexá-la junto às principais bases de periódicos internacionais. Isto reflete uma vontade ao mesmo tempo científica, política e filosófica para alcançar um patamar diferente, projetando a revista numa situação especialmente favorável para os seus usuários.

Os novos objetivos e escopo da RBG foram determinados e informados aos sócios, numa circular específica, em março de 2012, e publicados no número de junho. Para atingi-los, a SBG criou um Conselho Editorial e profissionalizou a operação editorial. O novo Conselho compreende 15 membros brasileiros e 15 estrangeiros, todos com status internacional e de comprovada competência. Sua composição vem anunciada neste número, e o colega Claudio Riccomini foi designado Editor Adjunto. Eles terão autonomia e poder de operar o sistema editorial, e poderão escolher revisores em qualquer parte do mundo. A operação do sistema já está afeta aos serviços profissionais de empresa de comprovada competência, que mantém uma estrutura de secretaria para a RBG e providencia tudo o que concerne à produção editorial, incluindo diagramação, revisão de provas, impressão e distribuição.

A Geologia brasileira é muito respeitada no plano internacional, pela atuação de nossa comunidade, tanto profissional quanto acadêmica. Com efeito, há brasileiros publicando material de grande interesse para as Geociências em veículos do exterior. Em contraste, em nosso país, embora existam mais de 30 revistas técnico-científicas que se ocupam das Ciências da Terra, elas não estão inseridas no âmbito internacional. Ou seja, seus artigos são pouco citados nos sistemas de indexação, portanto seu fator de impacto (FI, ou seja, número médio de vezes em que o artigo é citado por outros no biênio anterior) está muito próximo de zero. Infelizmente, este é também o caso da RBG.

Qualquer nação que almeje fazer ciência de fronteira precisa de revistas especializadas que acolham e reflitam essa ciência e, obviamente, isto vale para a Geologia. Entretanto, ainda não há veículos brasileiros disponíveis para exibir os trabalhos de Geologia de alta qualidade produzidos por aqui.

A meu ver, a RBG deve apresentar-se na esfera internacional, publicando o que de melhor se produz no tocante ao conhecimento geológico do território brasileiro. O que isto significa? Claramente, se pretendemos que a RBG torne-se uma publicação científica visível, atrelada ao Institute of Scientific Information (ISI) e ao Web of Knowledge, sua qualidade e regularidade devem ser confirmadas, e boa parte de suas contribuições deve ser feita na língua da Ciência, o inglês.

Com relação a esse último ponto, é essencial que os usuários normais da RBG sejam convencidos das vantagens em conseguir visibilidade global. Quero deixar claro que a revista não deixará órfãos os colegas que desejam ver seus artigos publicados em português, ou seja, manuscritos poderão continuar a ser submetidos em 
português e também espanhol. Entretanto, como consta no novo escopo da revista, a língua inglesa terá prioridade. Isso está sendo considerado tão importante que, no momento, a SBG está providenciando versões para o inglês de alguns manuscritos escolhidos, após obter a devida autorização dos autores.

Muito poucos leem no idioma português no exterior. Bibliotecas internacionais não assinam periódicos em nossa língua e, mesmo quando os recebem por intercâmbio, não os expõem. Com isso, publicar em português significa esconder o assunto no plano internacional.

Nos últimos dez anos e, especialmente após o intercâmbio intenso que ocorreu com o Congresso Internacional de Geologia do ano 2000, organizado no país, muitos membros de nossa comunidade buscaram e adquiriram notoriedade como nunca antes por meio de excelentes artigos publicados em revistas de prestígio de outros países. Acresce que isto ocorreu e ocorre ao custo de um grande esforço de cada um para superar barreiras de desconforto, associadas a certa discriminação por parte de muitos relatores levando em conta a ciência do hemisfério Sul. Ou seja, esses nossos colegas já fazem isso normalmente, na atualidade. Porque não fazê-lo por meio da RBG?

Muitas sociedades coirmãs da SBG já possuem, há algum tempo, revistas brasileiras publicadas em inglês, e, como tal, elas estão obviamente indexadas no ISI. Como exemplos menciono, entre outros, o Brazilian Journal of Physics, o Journal of the Brazilian Chemical Society, o Brazilian Journal of Analytical Chemistry, o Brazilian Journal of Biology e o Brazilian Journal of Medical and Biological Research, este último patrocinado por oito associações científicas brasileiras. Cabe lembrar que, no momento, apenas duas revistas que cobrem áreas especializadas das Geociências, a Revista Brasileira de Paleontologia e a Revista da Escola de Minas, de Ouro Preto, se encontram indexadas no ISI, ao lado dos Anais da Academia Brasileira de Ciências, que por outro lado cuidam de todos os setores científicos.

Cabe assinalar também que a revista da Sociedade Brasileira de Geofísica (SBGf) já há algum tempo chama-se Brazilian Journal of Geophysics, e, a partir deste ano, é publicada inteiramente em inglês. Mais do que isso, a SBGf está até bancando as despesas da versão para o inglês, temporariamente, dos manuscritos aprovados para publicação que foram submetidos em português. O fator de impacto médio das revistas brasileiras indexadas é da ordem de 0,5 , e as duas revistas mais bem colocadas para esse índice são a Clinics e a Memórias do Instituto Oswaldo Cruz, com FI próximo de 2,0. Será muito gratificante se a RBG, em cerca de quatro anos, conseguir indexação no ISI, e um FI entre 0,4 e 0,8 . Esta é a meta.

Vai aqui exposta a situação editorial atual da RBG, bem como as suas aspirações para os próximos anos. Com o volume 43, a revista mudará de nome, passando a chamar-se Brazilian Journal of Geology, com o acréscimo "former Revista Brasileira de Geociências". Por que Brazilian? Porque pretende publicar material a respeito de nosso território, de âmbito amplo, mais do que local. Por que Geology? Porque seu escopo está sendo redimensionado, buscando originalidade, inovação e significância para as ciências geológicas, deixando à responsabilidade de revistas congêneres artigos de geografia física, geofísica e ciências atmosféricas, entre outros, que de qualquer forma fazem parte das Geociências.

Para concluir, quero deixar o meu melhor agradecimento à diretoria da SBG pela confiança em mim depositada e pelo continuado suporte nesta fase de reestruturação da RBG. Quero agradecer também aos colegas brasileiros e estrangeiros do Conselho Editorial, por estarmos juntos neste desafio. Tenho certeza que a comunidade geológica nacional continuará a colaborar, para garantir o fluxo de manuscritos de qualidade. Em especial, gostaria que os colegas que no momento publicam seus resultados de pesquisa no exterior, em tópicos de fronteira da Ciência, também prestigiassem a RBG. A todos, peço que encaminhem, sempre que possível, as suas submissões em inglês. Finalmente, subscrevo plenamente a comunicação que a diretoria da SBG enviou recentemente aos seus associados, conclamando todos a participarem ativamente desta nova etapa da história da revista, em busca do aprimoramento da sua qualidade editorial e científica, da sua completa indexação e da visibilidade internacional.

Umberto Cordani Editor-chefe 